\title{
The Effect of University Marketing Efforts on Students' Academic Decision-Making: An Empirical Study
}

\author{
Connor Chase \\ Sales District Leader at PepsiCo \\ Susan Geringer \\ California State University, Fresno \\ Andreas Stratemeyer \\ California State University, Fresno
}

This study examines the influence that university marketing tools focusing on certain demographics (i.e., gender and age) have on students' academic decision-making. The marketing students sampled rated their decision-making process in regards to college selection, selection of a Business Administration major, and selection of an option within that Business Administration major. The findings indicate that university marketing efforts are more influential for younger students already enrolled regarding their choice of a college or school. Refined university outreach programs are necessary to better inform and direct students' post-enrollment decision-making.

Keywords: University, Marketing, College, Major, Option

\section{INTRODUCTION}

Since the introduction of student fees and universities' increasingly stringent student selections, Higher Education (HE) has evolved into a consumeristic battle for the maximum exchange of value between university and student (Chapman, 1981; Lusch, Vargo, \& Tanniru, 2010). A strategy based on consumer behavior is more advantageous to both the university and student, due to competition amongst universities to attract the best talent, in addition to students' academic choices being based on their perceived value of university offerings (Chapman, 1986; Maringe \& Gibbs, 2009). The high-stakes nature of HE necessitates an emphasis on the need for universities to understand consumer (student) decisionmaking (Maringe, 2006). The current study focuses specifically on university outreach and the certain tools used in guiding students' choice of college, major in Business Administration, and option within that major. A perusal of the literature indicates that there is deficient knowledge examining university outreach efforts made to influence students' post-enrollment academic choices. 


\section{Student Decision Making: Consumer vs. Learner}

The present study takes a consumeristic approach to the marketing of HE due to the high complexities in the competitive nature of the university selection process. It also establishes a basis for consumer behavior as an economic exchange, or rather, consumer behavior as anything to do with somebody's or a group of people's behaviors in relation to exchange of both tangible and intangible goods. In his seminal study, Chapman (1981) illustrates a model of student college choice that is inherent in understanding student decision making. Prior to Chapman's (1981) research, little knowledge existed as to what influenced students' college choice due to a high supply of students that allowed admissions offices to focus on selection, as opposed to recruitment. Chapman's (1981) study assisted in pioneering the shift within HE, from viewing academically-equipped students as an abundant source of supply to appreciating students as valuable customers. Consequently, HE now demands a high personal involvement in the decision-making process due to its long-term implications and competitive atmosphere, in which both universities and students strive to attract or attend the best university.

\section{University Approaches to Understanding Student Decision-making}

The literature to date indicates why universities' knowledge of consumer behavior is important for enrollment planning, marketing to students, and recruitment (Paulsen, 1990). In addition, Paulson (1990) states that when applying the marketing concept to HE, a university must identify their competition, determine their desired image and market position, and target a market segment.

When applying Consumer Behavior to HE, universities must take into consideration and understand the choice and decision-making processes of desired applicants to help develop the university's image. In order for a university admissions staff to be successful in contacting prospective students in an effective way, at the appropriate time, research and a solid marketing plan are key (Hossler, 1999; Hoyt \& Brown, 2003; Maringe, 2006).

\section{University Student Promotions}

Studies indicate that HE has not only become consumeristic in nature, but has also utilized chief marketing principles, such as the marketing mix, to provide universities with a relatable model. The results of Ivy's study (2008) indicate that universities have a strong emphasis on selling themselves, wherein the promotional activities that were most highly stressed included: school career counsellors; direct mail; open days on campus; and recruiter visits to high schools.

Hossler (1999) emphasizes timing and personalization as the two guiding principles in which university outreach should be tailored. If a university practices proper timing in relation to a student's decision-making process, the student will not feel rushed into making a choice or disregard a lagging university. Personalization creates a sense in prospective students that the university reaching out to them actually cares and has put thought into them, so that they should reciprocate the effort.

Once a student has declared their HE aspirations, he/she has entered the first step of the decisionmaking process with the recognition of a problem (Moogan, Baron, \& Harris, 1999). Veloutsou, Lewis, and Paton (2005) concluded that a student's subsequent decisions about a university has largely to do with information controlled by the university, such as a prospectus.

After reviewing the current literature regarding university recruitment and materials, the current study establishes three channels of outreach universities may exercise for current students. These methods include: print materials; electronic materials; and personal contact.

\section{Printed Marketing Materials}

Printed recruitment materials are a standard method of contact for universities to distribute throughout the prospective student market. The most widespread outreach methods universities utilize are direct mailings to prospective students and counselors, and a shotgun-style mailing sent out to high schools, career services centers, and libraries (Moogan \& Baron, 2003; Veloutsou et al., 2005). In addition, Chapman (1981) found that although these printed materials may be influential, they do not appear to be achieving the intended level of influence. 


\section{Electronic Marketing Materials}

Brown, Varley, and Pal (2009) observed that the internet is the greatest source of information used by students in the college decision-making process because university websites are viewed as the most up-todate source of information available. These authors found that the internet is the most used source of information for prospective and current students. Students prefer to gather information from the university website, over social media, due to the ease and validity of accessing specific information (Herren, Cartmell, \& Robertson, 2011; Veloutsou et al., 2005).

\section{Personal Contacts}

The literature suggests that universities may also reach prospective and current students through the use of personal contacts (Garner \& Dombrowski, 1997). These personal contacts include university campus visits, recruitment officers visiting high schools, or even interactions between prospective and current students (Garner \& Dombrowski, 1997; Kealy \& Rockel, 1987). Previous studies found that open days created the strongest impressions of the university on prospective student attendees (Herren et al., 2011; Moogan et al., 1999). In their study, Herren et al. (2011) found that campus visits were the most useful resource in recruiting students. Based on these findings, universities may view personal contacts as the most effective mode of influencing student's decision-making.

\section{Student Higher Education (HE) Choices}

Nulty and Barrett (1996) found that the majority of learning styles of first year students does not align with their particular discipline of study, due to the initial challenges of becoming accustomed to collegestyle learning. Brown et al. (2009) examined the affects that university communications have on students' decisions regarding major and course choice and determined that university-wide marketing communications may be effective.

Maringe (2006) found that university professors exude greater influence than parents, and are the greatest external factor on students' course choice. Burnaby, Howe, and Malgwi (2005) found that students switch majors because of positive factors about their new major, rather than negative attributes about previous majors. In addition, de Valero (2001) found that if departments can be better informed, they may be able to apply more stringent performance standards and accelerate student completion times, thus reducing the losses in student retention.

Pritchard, Potter, and Saccucci (2004) concluded that Schools of Business should assist their existing and potential students in the selection of a Business Administration major by informing them of important factors related to that major. These authors also described the necessity for coordination of internal communications between university admissions, counseling, and their Business Administration School.

To date, considerably less research has been conducted to analyze ways in which universities influence students' selection of a Business Administration major, as well as options within that major. The limited literature tells us that the greatest influence universities may have on students' selection of a Business Administration major and option depends on their ability to convey the various career opportunities that that major/option offers (Burnaby et al., 2005; Garner \& Dombrowski, 1997; Maringe, 2006). The current study aims to further analyze the tools, and their effectiveness, universities use to influence students' selection of a college, as well as provide new insights into those influences regarding major and option (see Figure 1). 


\section{FIGURE 1}

\section{UNIVERSITY STUDENT CHOICE MODEL}

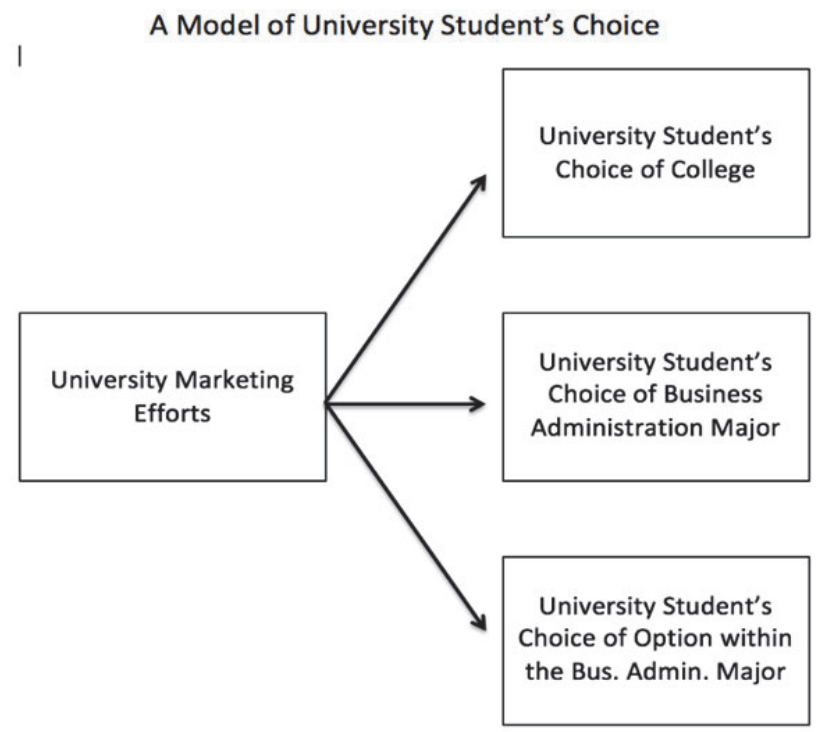

\section{RESEARCH DESIGN AND METHODOLOGY}

\section{Model}

In a seminal paper concerning influences on prospective and current students' choice of college, Chapman (1981) establishes internal and external influences as the two categories effecting students' decision-making processes. In Chapman's (1981) model, external influences that effect students' decision-making processes involve college efforts to communicate with students. The current study aims to further explore this portion of Chapman's (1981) model to examine the influences on students' decision-making processes, specific to university outreach. The model shown above was derived from Chapman's (1981) model and developed for this study, and is provided to illustrate what the current study examines: university marketing efforts and how they influence students in their decision-making processes when choosing a college, a major, and an option (i.e., marketing).

\section{Survey Instrument}

The survey used for this study was designed based on pre-existing scales within the marketing literature, in addition to a personal interview with a university Director of Undergraduate Recruitment. Specifically, the items to measure the three dependent variables were based on the marketing literature, and tapped into the three common university outreach channels regrading printed marketing materials, electronic marketing materials, and personal contacts. The questionnaire items measuring these dependent variables were established on a 7-point Likert scale and distributed to undergraduate marketing courses at a large public university located in the western United States. In addition, based on the personal interview, the questionnaire also contained two items (i.e., gender and age) to measure the independent variable and the effects of university marketing efforts.

A total of 380 responses were collected, of which 314 viable surveys were analyzed. The discarded questionnaires were either incomplete, or the respondent was not a business major. Students participated voluntarily and anonymously, and the surveys were completed via a pencil and paper format within the classroom environment. 


\section{Measures}

The independent variable (university marketing efforts) was measured across two separate demographic variables: gender and age. A chi-square test of independence (see Table 1) suggests that gender and age are independent (chi-square $=2.07, d f=3, p$-value $=0.56$ ).

TABLE 1

THE RELATIONSHIP BETWEEN GENDER AND AGE

\begin{tabular}{|l|c|c|c|}
\hline Gender/Age Group & Male & Female & Total \\
\hline 15 to 21 & 48 & 56 & 104 \\
\hline 22 to 25 & 86 & 79 & 165 \\
\hline 26 to 30 & 12 & 10 & 22 \\
\hline Over 30 & 14 & 9 & 23 \\
\hline Total & 160 & 154 & 314 \\
\hline
\end{tabular}

Summated scores for each of the three dependent variables (i.e., college, major, and option) was used to determine internal consistency measures in the aforementioned model. These three dependent variables were reliable, based on the following Cronbach alphas (see Table 2).

TABLE 2

DEPENDENT VARIABLE SCALE COEFFICIENT ALPHAS

\begin{tabular}{|c|c|}
\hline $\begin{array}{c}\text { Dependent Variable } \\
\text { Scale }\end{array}$ & Cronbach Alpha \\
\hline Choice of College & .918 \\
\hline Choice of BA Major & .943 \\
\hline Choice of BA Option & .947 \\
\hline
\end{tabular}

\section{Research Questions}

University recruitment efforts, particularly those submitted through printed materials, social media and personal contacts, have produced varied findings in previous research; this indicates such efforts may be either successful or unsuccessful in attracting students (Brown et al., 2009; Daun-Barnett \& Das, 2013; Kealy \& Rockel, 1987; Lumsden \& Armstrong, 2000; Simoes \& Soares, 2010; Veloutsou et al., 2005). Based on Figure 1 above, the following research questions are posited:

RQ1: What effect will university efforts have upon a student's choice of a college (i.e., a College of Business)?

The first research question addresses whether a university's outreach marketing efforts has any effect on a student's post enrollment decision regarding their choice of a college/school. Assuming that these efforts produce Business students, the following question is whether these students will become marketing majors. This leads to the next research question:

RQ2: What effect will university efforts have upon a student's choice of a major within a College of Business?

The choice of a Business major is based on several factors. The limited amount of research that does exist suggests that a student's decision between Business Administration majors depends on their quantitative skills and realistic information provided by the university (Pritchard et al., 2004). The final 
research question is based on the choice of an option within a particular Business major (i.e., Sports Marketing, Logistics, etc., within the Marketing major):

RQ3: What effect will university efforts have upon a student's choice of an option within a College of Business Major?

The current study will examine these three research questions and the influence that university marketing efforts have on students' decision-making in regards to their college selection, selection of a Business Administration major, and option within that Business Administration major.

\section{DATA ANALYSIS}

In order to test the three research questions and whether the dependent variables are impacted by these university marketing tools (i.e., gender and age), the survey data was analyzed using SPSS. Independent-samples t-tests and one-way ANOVAs were run to determine the statistical differences between the means of two or more groups (Hair, Babin, Money, \& Samouel, 2003). Again, summated scores were used for each of the dependent variables (i.e., college, major, and option) in the analyses.

\section{Findings}

The following table (see Table 3) illustrates the overall effectiveness of university marketing tools based on gender using three independent-samples t-tests. Overall, there is no significant difference when it comes to university outreach programs regarding gender and the three dependent variables concerning choice of college, major, or option $(t=0.29,0.19,0.03, d f=313, p$-value $=$ non-significant, respectively $)$.

Specifically, both males and females averaged between 2.9 and 3.3 on all dependent variable scales across choices regarding college, major, and option (where $1=$ strongly disagree; $7=$ strongly agree). Both genders seem to be rather apathetic when it comes to their decisions regarding choices of a college, a major, or an option. These results are consistent with the findings of Chapman (1981), Maringe (2006), and Tucciarone (2007), suggesting that university outreach programs are somewhat non-influential on student's academic decision-making.

TABLE 3

\section{HIGHER EDUCATION CHOICE DIFFERENCES BASED ON GENDER}

\begin{tabular}{|l|c|c|c|c|}
\hline Gender & Male & Female & $\boldsymbol{t}$ & $\boldsymbol{p}$-value \\
\hline Choice of College & 3.3 & 3.3 & 0.29 & $0.77^{*}$ \\
\hline Choice of BA Major & 3.0 & 3.0 & 0.19 & $0.85^{*}$ \\
\hline $\begin{array}{l}\text { Choice of BA } \\
\text { Option }\end{array}$ & 2.9 & 2.9 & 0.03 & $0.98^{*}$ \\
\hline
\end{tabular}

Note: ${ }^{*} p=$ n.s. (non-significant)

When looking at the impact that university outreach programs regarding age have on HE decisions, some interesting differences emerged (see Table 4). Based on the results of three separate ANOVAs, the age range of 15 to 21 seems to be more open to university marketing tools concerning the choice of a college. Specifically, the average responses from the 15 to 21 age range (mean $=3.7$ ) are significantly higher (where $1=$ strongly disagree, $7=$ strongly agree) across all other age ranges when it comes to the choice of a College of Business $(F=5.94 ; d . f .=3,310, p$ value $=0.00)$.

However, there were no significant differences between age across the other two dependent variables of HE choices (i.e., major and option). Apparently, age does not impact the selection of a Business major or option. Although there were no significant differences across age regarding HE outreach efforts concerning the choice of a Business major or option, the 15 to 21 age group mean was still higher than all 
other age groups. This suggests that younger student are more likely to be influenced by university outreach programs.

The interesting differences in age ranges implies that university marketing tools may have a greater effect during the earlier stages of student's HE decision-making, which supports Hossler's (1999) notion of timing and personalization being the key guiding principles of university outreach.

Of course, sample sizes might have an impact on ANOVAs, but every age group across all ANOVAs had at least 20 or more respondents per group, suggesting that the results are reliable (Hair et al., 2003).

TABLE 4

HIGHER EDUCATION CHOICE DIFFERENCES BASED ON AGE

\begin{tabular}{|l|c|c|c|c|c|c|}
\hline Age Group & Over 30 & $\mathbf{2 6}$ to 30 & $\mathbf{2 2}$ to 25 & $\mathbf{1 5}$ to 21 & $\boldsymbol{F}$ & $\boldsymbol{p}$-value \\
\hline Choice of College & 2.7 & 3.0 & 3.1 & 3.7 & 5.94 & $0.00^{*}$ \\
\hline Choice of BA Major & 2.8 & 2.8 & 2.9 & 3.3 & 2.34 & $0.07^{* *}$ \\
\hline $\begin{array}{l}\text { Choice of BA } \\
\text { Option }\end{array}$ & 2.6 & 2.6 & 2.8 & 3.1 & 1.80 & 0.15 \\
\hline
\end{tabular}

Note: ${ }^{*} p<0.05 ; * * p<0.10$

\section{DISCUSSION}

There is an abundance of research pertaining to levels of influence university marketing tools have on students' academic decision-making in comparison to other factors; however, there appears to be a lack of knowledge as to how influential specific university marketing tools are when compared to one another. The current study provides research as to how influential certain university marketing efforts are overall with respect to gender and age during students' choices of college, Business Administration major, and option within a Business Administration major. Future research could look into the impact that other variables have on students' decision-making processes regarding the choice of college, major, and option.

Based on the results, gender was not an issue as a marketing tool in influencing students' postenrollment academic decision-making. Specifically, gender did not have any impact on students' higher education decisions regarding their post-enrollment choice of college, major, or option. Regarding age, younger individuals (i.e., 15 - 21 age range) were more inclined to respond to university outreach programs to determine a college when it comes to post-enrollment decisions.

Even though it was not significant, younger students were also more receptive to university outreach programs and other university promotions concerning their choice of major and option. In addition, all age groups seemed to decline in their interest toward university outreach programs as they progressed through their university careers.

Overall, Research Questions 1 - 3 shows that gender is not a factor, suggesting that this variable is not influential in students' post enrollment decision-making. Age was the only significant factor to have any impact on post enrollment choices, specifically regarding the choice of a college or school.

\section{MANAGERIAL IMPLICATIONS}

Based on the findings of the current study, university outreach programs may improve their effectiveness in marketing to enrolled students by maximizing efforts made and time spent using successful promotion tools. Specifically, personal contacts targeted toward younger students are more apt to address the real concerns of enrolled students (Maringe, 2006).

Despite the popularity of print and social media, universities may not be offering interesting or relevant content to enrolled students. Refocusing efforts to keep students rather than recruit new students is one of the basic tenants of the marketing concept. Applying this concept to enrolled students might influence their academic decision-making regarding the choice of college, major, and option. 
Printed marketing materials, electronic marketing materials, and personal contacts should be used in concert in order to increase the matriculation of enrolled students. Given the popularity of electronic marketing materials, simple adjustments should be made to keep information current and/or relevant for enrolled students. By improving a university's social media relevancy, enrolled students may recognize the content as more personalized, which may lead to greater interest in a university's offerings (Brown et al., 2009).

The implications of this study suggest that university outreach programs may lead to enhanced selection criteria for enrolled students. In turn, these students should be better informed regarding their choice of a college, major, and option.

\section{REFERENCES}

Brown, C., Varley, D., \& Pal, J. (2009). University course selection and services marketing. Marketing Intelligence and Planning, 27(3), 310-325.

Bryman, A., \& Bell, E. (2015). Business research methods. Oxford: Oxford University Press.

Burnaby, P., Howe, M., \& Malgwi, C. (2005). Influences on students' choice of college major. Journal of Education for Business, 80(5), 275-282.

Chapman, D.W. (1981). A model of student college choice. Journal of Higher Education, 52(5), 490-505.

Chapman, R.G. (1986). Toward a theory of college selection: a model of college search and choice behavior. Association for Consumer Research, 13, 246-250.

Daun-Barnett, N., \& Das, D. (2013). Unlocking the potential of the internet to improve college choice: a comparative case study of college-access web tools. Journal of Marketing for Higher Education, 23(1), 113-134.

de Valero, Y.F. (2001). Departmental factors affecting time-to-degree and completion rates of doctoral students at one land-grant research institution. Journal of Higher Education, 72(3), 341-367.

Garner, R.M., \& Dombrowski, R.F. (1997). Recruiting the "best and the brightest": the role of university accounting programs and state CPA societies. Issues in Accounting Education, 12(2), 299.

Hair, J.F., Babin, B., Money, A.H., \& Samouel, P. (2003). Essentials of business research methods. NJ: Leyh Publishing.

Herren, C., Cartmell, D., \& Robertson, J. (2011). Perceptions of influence on college choice by students enrolled in a college of agricultural sciences and natural resources. NACTA Journal, 55(3), 54-60.

Hossler, D. (1999). Effective admissions recruitment. New Directions for Higher Education, (108), 15-30.

Hoyt, J., \& Brown, A.B. (2003). Identifying college choice factors to successfully market your institution. College and University, 78(4).

Ivy, J. (2008). A higher education marketing mix: the 7Ps for MBA marketing. International Journal of Education Management, 22(4), 288-299.

Kealy, M.J., \& Rockel, M.L. (1987). Student perceptions of college quality: the influence of college recruitment policies. Journal of Higher Education, 58(6), 683-703.

Lumsden, D., \& Armstrong, J. (2000). Impact of university's promotional materials on college choice. Journal of Marketing for Higher Education, 9(2), 83-91.

Lusch, R.F., Vargo, S.L., \& Tanniru, M. (2010). Service, value networks and learning. Journal of the Academy of Marketing Science, 38, 19-31.

Maringe, F. (2006). University and course choice: implications for positioning, recruitment and marketing. International Journal of Educational Management, 20(6), 466-479.

Maringe, F., \& Gibbs, P. (2009). Marketing higher education: theory and practice. UK: McGraw Hill Education.

Moogan, Y.J., \& Baron, S. (2003). An analysis of student characteristics within the student decision making process. Journal of Further Higher Education, 27(3), 271-287.

Moogan, Y., Baron, S., \& Harris, K. (1999). Decision making behavior of potential higher education students. Higher Education Quarterly, 53(3), 211-228. 
Nelson, P. (1970). Information and consumer behavior. The Journal of Political Economies, 78(2), 311 329.

Nulty, D., \& Barrett, M. (1996). Transitions in students' learning styles. Studies in Higher Education, 21(3), 333-345.

Paulsen, M.B. (1990). College choice: understanding student enrollment behavior. ASHE-ERIC Higher Education Report No. 6, The George Washington University, Washington, DC.

Pritchard, R.E., Potter, G.C., \& Saccucci, M.S. (2004). The selection of a business major: elements influencing student choice and implications for outcomes assessment. Journal of Education for Business, 79(3), 152-156.

Simoes, C., \& Soares, A.M. (2010). Applying to higher education: information sources and choice factors. Studies in Higher Education, 35(4), 371-389.

Tucciarone, K. (2007). Vying for attention: how does advertising affect search and college choice? College and University, 83(1), 26-35.

Veloutsou, C., Lewis, J.W., \& Paton, R.A. (2004). University selection: information requirements and importance. International Journal of Education Management, 18(2/3), 160-171.

Veloutsou, C., Lewis, J.W., \& Paton, R.A. (2005). Consultation and reliability of information sources pertaining to university selection. International Journal of Education Management, 19(4), 279291. 